\title{
Competitive Strategy as Practice: Obtaining Differential Advantage in the SME
}

\author{
Barry Ardley, Sanngarri Naikar \\ Lincoln International Business School, University of Lincoln, Lincoln, UK \\ Email: bardley@lincoln.ac.ukD
}

How to cite this paper: Ardley, B., \& Naikar, S. (2021). Competitive Strategy as Practice: Obtaining Differential Advantage in the SME. Open Journal of Business and Management, 9, 196-212. https://doi.org/10.4236/ojbm.2021.91011

Received: December 4, 2020

Accepted: January 9, 2021

Published: January 12, 2021

Copyright (c) 2021 by author(s) and Scientific Research Publishing Inc. This work is licensed under the Creative Commons Attribution International License (CC BY 4.0).

http://creativecommons.org/licenses/by/4.0/

(c) (i) Open Access

\begin{abstract}
The purpose of this paper is to examine the implementation of competitive strategy processes in the SME. The topic was approached by using elements of practice theory to analyse activity in a range of different SMEs. The research method adopted was based on data collected from in-depth interviews with sixteen owner managers. Using practice theory as an analytical framework, it was established that the majority of the firms in the study utilised four key practices, in order to obtain advantages in the market place. A central strategy contributing to a successful competitive position revolved around key customer service processes, supported by other practices concerned with cost control, supplier and wider network partnerships. A range of practices are revealed regarding how the smaller firm can achieve a competitive advantage in the market place, having key implications for the management of strategy as practice, future research and theory generation. The value of this paper is that little work exists with regard to the application of practice theory in the SME. Consequently, our research helps to fill a gap in understanding the key relationship that exists between individual actors and the nature of the institutionally based strategic practices they inhabit and reproduce.
\end{abstract}

\section{Keywords}

Competitive Strategy, Competitive Positioning, Practice Theory, Qualitative

\section{Introduction: Strategy as Practice in the SME}

Competitive strategy and the development of the firm have long been discussed in the SME sector, both by academics and practitioners. This can be ascribed to the fact that activities in SMEs associated with product and process improvement, are of considerable interest, as they can lead to significant long-term growth (Love and Roper, 2015). Companies may develop through a takeover or 
merger, being transformed into a larger SME or other types of business, but there exist other ways in which an SME can progress, that do not necessarily mean a change in structure. In this context, for small and medium-sized enterprises, product development is often seen as a route to establishing a sound competitive position (Jones and Rowley, 2009). SMEs can also compete with firms of a similar type and the larger firm, by supplying an untapped niche market (Jones et al., 2013). Generally, the smaller firm can be a very effective operator in markets, a result of smaller organisational structures, flexibility, a lack of bureaucracy and because of good knowledge sharing with partners and suppliers (O’Donnell, 2011; Audretsch and Vivarelli, 1996). Additionally, SMEs usually have a short decision-making process due to fewer layers of management, greater functional integration, less resistance to change and a more innovation friendly atmosphere (Nicholas et al., 2011). However, SMEs, in their search for a workable competitive strategy, also face major challenges. This includes keeping the firm's capabilities, resources and routines up to date, maintaining entrepreneurial and managerial competences, acquiring new knowledge and combining the latter with existing organizational structures and routines Altinay et al. (2016).

In the light of these issues, how SMEs deal with the issue of competitive strategy is of importance not only to the firm, and the research community, but because these companies are key drivers of economic growth as well (Deakins and Freel, 2012). In this paper, we examine the approach adopted to competitive strategy by successful SMEs, based on research collected using a practice theory perspective. Here, we adopt an approach that moves away from a reductionist approach that looks at only one or two key characteristics, to one that embraces a more holistic viewpoint on the routines and regular practices that companies operate in carrying out their competitive strategies. Whilst the issue of context and different types of company is important, we will consider a range of SMEs, with a view to establishing some common practices. Consequently, we frame our research question in the following way. What is the nature of the recurring organisational practices in the SME that establish a successful competitive position in markets? In the next section, we outline some thinking on the notion of practices, and then follow it with a discussion of competitive issues and the SME and subsequently, with an analysis and discussion of the findings resulting from a series of face to face interviews.

\section{Practice Theory}

Writers like Bourdieu (1984), and Giddens (1984) both use the word practice in ways that are alike, with the focus on routines, shared habits, techniques and competences. This behaviour as practice necessarily depends on the specific interconnectedness of a range of elements which cannot be reduced to any one single factor. Practices in this sense can involve way of cooking, of consuming, of working and of looking after oneself and others. For Reckwitz (2002), any type of practice can be typified as involving bodies, minds, things, knowledge, processes, 
language and the individual agent's motivations and emotions. For Schatzki (1996) practice is about the performance of particular doings and sayings, in order to realise and perpetuate a routine. To add to this, Schau et al. (2009) argue that practices consist of three main elements. One relates to the following of a set of procedures, being rules and instructions and secondly, there is understanding, which is about having the knowledge of what to say and do. Finally, the engagement process represents the purposes that people are committed to in pursuit of the practice. What is evident here is that although we can say practices involve routines and the involvement of the individual, there is no one unified and overarching way in which they are articulated (Nicolini, 2012). As an example of a variation, Shove and Pantzar (2005), discuss how they see the various practices involved in the sport of Nordic walking, a form of speed walking using two sticks for support and propulsion. For these authors, the practice of speed walking entails the involvement of both consumers and producers, where there exists the active and ongoing integration of meaning, artefacts and forms of knowledge. Here they also note that even ordinary forms of recreational walking often depend on an array of requisite equipment, involving producers who supply boots, shoes, paths and maps, which are then used by consumers, who derive meaning from the sport and its artefacts.

Broadly speaking, the individual as a body and as mental agent, acts as the transporter of a particular practice, which are not features or qualities of that person. This represents an attempt, as Hargreaves (2011) points out, to establish a middle level between agency and structure. The practice itself, rather than the individuals who perform it, or the social structures that surround them, therefore becomes the core unit of analysis. This does not, however, reduce individuals to submissive dupes, bound to the dictates of practice, but instead it is possible to conceive of people as skilled agents who actively negotiate and perform a wide range of practices in the normal course of everyday life (Warde, 2005). In a more fundamental sense, the practice approach draws on Giddens (1984) and his work on structuration theory. Giddens describes structures as being about resources, systems and guidelines, and agency, as about the human actors who exist within these structures. The constant interface between agency and structure constitutes a duality, which means that social structure is reproduced by repeated human actions, and interactions, while structure enables and compels that human action (Buhr, 2002). Consequently, practices inhabit the middle ground between the person and the structure.

\section{SMEs, Competitive Strategy and Practice}

Importantly, people working in a business, be it small or large one, must develop a shared understanding of what practice involves and be able to competently and willingly execute its performance. Like other business activities and processes, competitive strategy can also be viewed from a practice perspective. Usually, once having determined the market segment, competitive strategy is concerned 
with either the practices of cost leadership, or of differentiation in order to gain advantages in the market place (Hooley et al., 2017). Differentiation can be obtained in a number of ways, for example through product design, brand image, or service. The strategies are not mutually exclusive and differentiation can be combined with cost leadership (Wilson and Gilligan, 2012). For the purposes of this paper, we adopt the approach of Schau et al. (2009) where practices link behaviour, performance and representation, through the three elements indicated earlier, of procedures, understandings, and engagements. These elements conveniently capture what practice is about; namely, the implementation of rules and principles, the knowledge of how to carry out the practice and having a purpose attached to the same practice. For example, competing through high service provision will involve a set of practices that might be about speed of performance, customer engagement processes and after sales care.

In this paper, we follow the work of Echeverri and Skålén (2011) in adopting this three-element construct of practice, where they studied in a transport context, interactive value formation at the provider-customer interface. In the context of a business, these three elements can be equally attached to factors that are key aspects of competitive strategy, like the execution of customer service and the building and maintenance of relationships with other organisations in order to achieve a value position in the market. Properly implemented, customer service can be a significant feature of the firm leading to differentiation, a strategic practice, involving staff who are trained to provide high quality end results to customers (Hapsari et al., 2017). Strategy is designed so that employees not only help to attract new consumers, but are also able to build existing customer relationships, in order to sustain and develop loyalty and excellent customer experiences (Abadi et al., 2020; Wei and Nair, 2006). At the other end of the continuum for the SME, there is also the issue of costs. Growth and development do not just come from concentrating on customer service and relationships, but also from a careful marshalling of resources and paying attention to the control of costs. In order to remain competitive, the small firm must minimise these if possible (Pullen et al., 2009). In these areas, our research points towards a range of tools, norms and processes that make up the strategy work of customer service and cost control as key practice dimensions.

Additionally, a central contextual feature of many SMEs, is the nature of their network, one they operate with suppliers, and other influential players (Hanna and Walsh, 2002). Strong relationship ties and interactions are likely to promote in-depth exchanges and this provides the opportunity for people in the networks to share a variety of types of expertise. These can be shared network experiences, shared network mental models, and shared network-based knowledge (Christopher et al., 2013). All networks are unique sources of differentiation, containing not only suppliers but perhaps trusted advisers, recruiters, financiers and industry contacts. It can be argued that networks can be seen as representing key performative practices, which are resources of the smaller entrepreneurially inclined 
firm. These resources can be leveraged in a number of ways by for example, incorporating other companies' assets into your own to increase customer value, and in the case of costs, extending resources much more than others have done, or are able to do currently (Sadiku-Dush et al., 2019; Morris et al., 2002). As with customer service and costs, networks as strategy are embedded parts of the practice of the organisations we researched (Vaara and Whittington, 2012).

\section{Methodology}

The data for this paper was initially gathered for a different study of SMEs, but was then revisited. The original primary research containing interview data, was intended to examine both the intangible and tangible resources SME managers utilised in order to grow their SME business. These resources included staff skills, location, promotional events and brand assets like customer recognition. On the basis of the re-reading of the data transcripts, it became apparent that issues existed around some common practices carried out by staff and mangers in the execution of competitive strategy. In this respect, Watson (1995) makes the important point that every interview should be fully transcribed, because researchers may not fully realise the significance of something until it is reflected on later. In developing these insights, it should be noted that generally, practice theory directs the researchers to focus towards the "doing" of everyday accomplishments. Consequently, it implies the use of methodological techniques that are adept at observing what actually occurs in the performance of practice (Hargreaves, 2011). In terms of this paper and for reasons of confidentiality and access, we were unable to carry out observations but instead, rely on the accounts given to us by the owner-managers interviewed. This should not necessarily be seen as a weakness, as (Nicolini, 2009) argues that instead of being preoccupied with whether we can get enhanced admittance to practice through observation and participant observation, or other visual means, researchers should ask to what degree a particular method is best sensitive to the nature of a practice.

Seen in this context, an interview only approach was successfully adopted by Echeverri and Skålén (2011), in their work on value creating practices in the public transport industry. Consequently, we argue that our interpretivist interview method allowed respondents the time and scope to talk in an in-depth way about practices relating to management and staff activity within their organisations. This freedom enabled respondents to range widely and to also, focus on articulating particular processes in their organisations, which was of benefit, as it enabled the researchers to elicit accounts of practice (Ashton, 2014). In following Kvale (1996), our use of interviews therefore made possible the building of rapport, the asking of probing questions and the reporting of critical practices, as perceived by the interviewee. The process of data analysis involved constructing a series of themed practice elements for investigation, reflecting a discourse analytic approach (Paltridge, 2006). 
All the firms featured in the research here had been in business for over three years and conform to the definitions of small and medium sized enterprises as indicated by the European Union (EC, 2015). The firms are diverse, representing a wide range of backgrounds, both in the $\mathrm{B} 2 \mathrm{~B}$ and $\mathrm{B} 2 \mathrm{C}$ sectors. The firms in the original sample were in importing and exporting, retail, telecommunications, marketing and business services, outdoor activities, printing, corporate well-being, training, hearing care and consultancy, being drawn from the United Kingdom (UK) and Singapore (SG). In total, sixteen senior personnel were interviewed, representing small and medium sized companies. With each interview lasting up to ninety minutes, the researchers had about twenty-five hours of data to examine. Here, for the current paper, we do not draw on all our respondents, but use eight informants, in order to present a general perspective on practice activity. These informants are the owner managers of the enterprises researched, so can speak knowledgeably and authoritatively about their firms. The following Table 1 summarises our sample company characteristics.

In justifying a small sample approach, Hackley (2019) points out that all data is meaningful and can be seen as an end in itself, provided it is analytically focused. In developing this perspective on small scale research, it is argued that the research here meets the criteria of soundness which can be applied to research that is interpretive. Marshall and Rossman (2016) point out that in assessing this type of research what needs to be taken into account is that the design and methods of the study are explicitly detailed, the work is situated in a scholarly context, records have been kept and it has been made clear how the data is to be interpreted and made relevant to the research questions posed. Here, the research will contribute to the debate regarding practice theory and competitive strategy. We now move to the presentation and discussion of our findings, highlighting the practices of service, cost control and networks in achieving competitive differentiation in our firms.

\section{Customer Service Practice: Ensuring a Quality Provision}

Significantly, competitors maybe unable to effectively sustain good relationships with customers if service is not a highly valued central practice within their business concerns. Studies by Hu et al., 2009; and Tam (2004), suggest that service quality practice drives customers' perceived value and the better the service quality, the higher the customers' perceived value of the enterprise and the products in question. The twin competitive issues of attracting new customers and retaining existing ones through staff and the quality they provide, is made by our informant representing a retail and wholesale distributor of traditional imported Indian products.

"Customers come into constant contact with our staff members, when that happens staff need to be able to please them, so that they keep the customers coming back. So, quality you see is essential. People know our name and the word will spread if they get bad quality service". 
Table 1. Sample company characteristics.

\begin{tabular}{|c|c|c|c|c|}
\hline Company type & $\begin{array}{l}\text { Company age } \\
\text { in years }\end{array}$ & Location & $\begin{array}{r}\text { Number of } \\
\text { employees }\end{array}$ & Company markets \\
\hline Hearing Care & 5 & UK & 5 & $\begin{array}{l}\text { Sale of consumer hearing } \\
\text { products }\end{array}$ \\
\hline Business Services & 6 & UK & 2 & $\begin{array}{l}\text { Organising events and } \\
\text { networking for SMEs }\end{array}$ \\
\hline Printing & 23 & UK & 5 & $\begin{array}{l}\text { Copying, graphic design, SME } \\
\text { and final consumers }\end{array}$ \\
\hline Consultancy & 10 & UK & 7 & $\begin{array}{l}\text { Construction industry, town } \\
\text { and country planning }\end{array}$ \\
\hline Digital Marketing & 4 & UK & 6 & $\begin{array}{l}\text { Website design and development, } \\
\text { video production }\end{array}$ \\
\hline Marketing Services & 3 & UK & 1 & $\begin{array}{l}\text { Serving marketing needs } \\
\text { of micro businesses }\end{array}$ \\
\hline $\begin{array}{l}\text { Import-export of } \\
\text { Indian products }\end{array}$ & 29 & SG & 47 & $\begin{array}{l}\text { Buying and selling of } \\
\text { traditional products }\end{array}$ \\
\hline $\begin{array}{l}\text { Import-export of } \\
\text { electronic goods }\end{array}$ & 3 & SG & 20 & $\begin{array}{l}\text { Mobile phone related } \\
\text { products }\end{array}$ \\
\hline
\end{tabular}

Staff working with customers in this way, being able to demonstrate high quality levels of expertise, means that doing business is much more attractive to the customer. This can enable the firm to develop solution based practices through a long-term dialogue (Ballantyne, 2004). Another example of the role of high-quality service and customer retention is provided by another informant, the owner of a business that provides customers with hearing products.

"Quality of service helps keep the customer happy. If you are not smiling not friendly, not courteous to your customers, they would not be willing to come back, just because of the experience. The hearing business is such that in order to really understand individual problems, you have to spend time talking and understanding them so that at some point, our customers start to have a long-term relationship with us. That is what defines us and keeps us different".

The fragility of the customer relationship, in that it is vital to maintain a value service consistently, is starkly made by our informant from a business services firm. "Good quality service is fundamentally important, because my customers can vote with their feet, anytime they wish".

So not as to have the situation where customers are "voting with their feet" the following quote from our importer-exporter of traditional Indian products, points out that the processes of "explaining", "friendliness" and "approachability" are key aspects of ensuring a quality customer service experience is provided. 
"Good quality of service, is very important, because the nature of business is the need to explain to customers what they are buying and what to do with the items they buy. So, if our staff are not friendly, not approachable, it is a very big issue for us".

These companies reflect the three practice elements of Schau et al. (2009) that relate to the areas of customer service strategy. For the owners of these companies, a central purpose of their business is to provide a high level of customer service and it is a similarly important commitment for staff. Commitment to this purpose, represents the practice element of engagement. For example, one respondent from the hearing company makes the point about the need to "talk" to customers, and another respondent, from the distributive outlet, discourses about the importance of "pleasing" customers. Both these activities of pleasing and talking to customers suggest that the knowledge which is necessary of how to do this effectively, will come from the instructions and training generated by the firm and also from the experiences built up over time by employees and managers.

\section{Cost Control as a Competitive Practice in the SME}

In attempting to achieve competitive strategy, it is important for firms in the SME sector to not only have a service strategy and ethos, but to also have a commitment to build controllability into its operations. Man et al. (2002) characterise this as cost-effectiveness, representing the ability to set a competitive price. Our companies understand that cost control is important and are committed to achieving it. Also important is the ability to put procedures of cost control into practice. When asked how important it is to try and reduce costs in order to maintain competitiveness, our respondent from an importer-exporter of electronic goods SME, pointed out that it is important not to incur costs by holding onto stock. This shows the commitment and the procedure of cost control, in action.

Cost control is, "Very very important. It is the deciding factor in picking the products. There are days when you have to sell at cost, because it is a very volatile market. You come in, three other people have got the stocks and I have to let go. You can't make money every day in this business, there is no safety net, you are on your own, and no one is going to catch you if you faip'.

In another business context, our respondent from the hearing industry emphasises this point about costs in relation to the question posed about cost and competitiveness. "To me it is vital, costs are everything, because you can offer a cheaper product if you have got your costs in place, so the only really way to be successful is to cut our costs". Whilst the target customer segment is of importance in this example, so is the cost dimension of strategy practice, as it is for the majority of our other companies. From another perspective, the representative from our printing company summarises the challenges that the small business 
faces in considering the issue of costs, resources and practices in terms of purpose, knowledge and procedures. Commitment to cost control appears paramount, coupled with a knowledge of the different types of cost and how these can be operationalised.

"It is important to keep cost down, especially as printing is very erratic, so by trying to keep our overheads low, by not having machine lease fees and by being off the high street, our business overheads are not as high. So, keeping fixed costs down, means that it gives the flexibility to accept quieter periods and then you make money in your busy periods".

In overall terms respondents here appear to be inferring that systematic processes relating to costs are in place as means of control and the regular practice of attending to them is well summarised by our respondent representing a training services provider... "each day we have to start looking more strongly at cost, so commercially we have to say is it worth doing that work...".

\section{Suppliers and SME Networks: Differentiation and Customer Value}

Alliances in networks were another practice our research highlighted, with our respondents indicating generally their high importance, where these alliances contributed to occupying a sound competitive position. Networks included other complementary organisations and individuals, as noted by our respondent from a digital marketing company.

"We regularly use people to write words for websites, we've got really strong alliances with people who can do that, and it's all the kind of horizontal services, so things that complement what we do and we have built really strong ties with them".

In discussing the nature of these broader network relationships, our respondent from a planning and consultancy company in construction, was asked if alliances were beneficial to the growth of the company.

"Yes, without a doubt. One of the reasons we've been able to grow the development side of the business is we formed alliances with both land owners and developers and of the service providers. In one particular example, we have an alliance with a consortium of land owners architects, conservation consultants, all agreeing to work on a common objective and to take fees from the end result, so those alliances are integral to the way we work'.

For an SME providing marketing services, network alliances are seen as central practices that assist in obtaining a competitive position in the market " $m y$ network of freelancers, without them the business wouldn't exist". This type of freelancing can include for example, digital specialists, providing voice overs for videos, web site designers and social media experts. Alliances are also important where this can also contain competitors that the firm will cooperate with when 
the need arises. Our example here is from our printing respondent.

"No printer can do everything, so one of the important things is being able to link to other printers who do other sorts of printing, so that if a customer comes to us and says, could you organise this for me, I need this, or could you organise that for me? If we can say yes, by getting a trade price from a different sort of printer bringing it in, then the customer, they' ve got a finished job, something from us and something from somebody else".

The importance of establishing networks as strategy practice and their strategic growth role in our firms, is well summarised by a respondent from a digital marketing company who stated that, ... we ve built the entire business on a model whereby networking is fundamental and it will take a lot more time to go out and build those networks further".

It is also evident from our respondents, that strong alliances with suppliers were a beneficial practice, necessary as a continued activity, to help them stay ahead of competitors. In terms of supplier relationships, significant reservoirs of knowledge exist within these boundaries (Cavusgil et al., 2003; Gummesson 2017), where these types of relationships will help the company function productively. Supplier relationships can facilitate the ability to work not only to mutually beneficial contractual arrangements, but also to trusted verbal agreements, covering a wide range of areas from pricing to shared distribution, to product development. It is possible to develop with suppliers' on-going collaborations and a point about networks, is that they are inimitable and are a key source of advantage (Menelec and Jones, 2015). Our informant from the import-export of electronics goods points out some of the practices involved in the supplier relationship.

"My biggest resource is the rapport I have with my supplier companies, no trust, no talk. I meet up with my suppliers every now and then, fly over, see them, just to catch up and make sure they keep remembering me." The respondent goes on to say that... if I don't have a good relationship with them, it will be difficult for me to even do business in the first place. This is part and parcel of my line of business, we must have good relationships, always'.

For the company in the hearing industry, a continuous cooperative working relationship is seen as a central practice that will ultimately create value for the final customer. "We have to continue working with the manufacturers that, is essential. Without the relationship, there, we will not be able to gain the right prices for specific products". The practice of working closely with the supplier manufacturers staff, is also commented on by the same respondent. "If you are talking about alliances, it is to the manufacturers support staff where you know that if something goes wrong, you can call, say John and say, I have an issue, can you fix this and he gets on and does it".

Explicit practices need to exist in dealings with suppliers and other network 
members that can include the building of collaborative business models, as is the case with our respondent from the digital marketing company. Generally, it is clear that these alliances represent a significant resource, where purpose and knowledge are needed to make them work. Finally here, although not mentioned by our respondents, tacit expertise is worth some consideration.

The tacit arguably represents an important "unseen" practice, it is not explicitly documented, but still is apparent in the way a firm operates (Kaptan, 2013; Hackley, 2000). For example, staff may regularly pass on to other staff, knowledge of their recondite experiences in successfully dealing with customers, a knowledge that is not in books of instruction. Cavusgil et al. (2003) argue that a competitive success capacity exists due to the tacit, as it is difficult for rivals to identify and replicate. This advantage might be evident where we think about our respondent above who sees it as important to build "rapport" with the supplier network, something that is arguably, a tacit practice. Additionally, tacit, experiential expertise enables firms potentially, to apply knowledge to a wide range of day to day operational activities, (Arnett and Wittmann, 2014), resulting in improved efficiencies and a better financial performance over competitors. Through the sharing of tacit experiences and practices, a firm should be able to prosper, because it has a key inimitable resource (Ardley and Quinn, 2014). In the three practice elements of Schau et al. (2009), the tacit dimension represents a uniqueness of procedure, a particular type of engagement and thirdly, an understanding that is beneficial to the implementation of competitive strategy.

\section{SMEs, Practice Dimensions and Competitive Positioning}

Table 2 below summarises our findings. Through the use of a practice lens, we show how SMEs can operate an effective competitive positioning strategy. The research question posed at the start of the paper, dealing with an attempt to find out what are the organisational practices in the SME that establish a successful competitive position in the market, has been addressed.

Our research indicates that a range of practice dimensions come together and operate synergistically as competitive factors, as customer service, cost control, supplier networks and other key alliances. Without these practices in place, these firms will likely find customers "vote with their feet" and move to a competitor, consequently cutting off routes to development. Table 2 represents a snapshot of our research, with the column "dimensions of practice" illustrating the processes undertaken by these firms in the pursuit of their competitive position in the market. These dimensions of practice as bundles of activities (Røpke, 2009), have a common composition, consisting of firstly set procedures and instructions, secondly understandings, which represents the knowledge of what to say and do, and finally engagements, which are the ends and purposes that people are committed to (Schau et al., 2009; Echeverri and Skålén, 2011). Our respondents have illustrated that evidence exists in their organisations of these three elements, being practices that link to the competitive factors of our centre column. 
Table 2. Strategic practices and competitive positioning.

\begin{tabular}{|c|c|c|}
\hline Elements of Practice & Competitive factors & Dimensions of Practice \\
\hline $\begin{array}{l}\text { Procedures } \\
\text { Understandings } \\
\text { Engagements }\end{array}$ & Customer service & $\begin{array}{l}\text { Practices associated with demonstrating product } \\
\text { knowledge, sustaining customer dialogues, } \\
\text { improving after sales service, building customer } \\
\text { relationships, developing service quality and } \\
\text { implementing service quality strategies }\end{array}$ \\
\hline $\begin{array}{l}\text { Procedures } \\
\text { Understandings } \\
\text { Engagements }\end{array}$ & Cost control & $\begin{array}{l}\text { Practices associated with controlling costs in order } \\
\text { to obtain effective selling prices, not holding onto } \\
\text { stock unnecessarily, control of overheads, the } \\
\text { regular day to day monitoring of costs }\end{array}$ \\
\hline $\begin{array}{l}\text { Procedures } \\
\text { Understandings } \\
\text { Engagements }\end{array}$ & Supplier networks & $\begin{array}{l}\text { Practices associated with building rapport with } \\
\text { suppliers, and continuous cooperative working } \\
\text { relationships, building reciprocity with individuals } \\
\text { and their firms in order to provide value to the } \\
\text { final customer }\end{array}$ \\
\hline $\begin{array}{l}\text { Procedures } \\
\text { Understandings } \\
\text { Engagements }\end{array}$ & Alliances in networks & $\begin{array}{l}\text { Activities associated with building relationships with } \\
\text { complementary companies and the development } \\
\text { of common objectives and mutually beneficial } \\
\text { strategic alignments, that are part of a customer } \\
\text { focused business model }\end{array}$ \\
\hline
\end{tabular}

There exists a considerable amount of research that examines purported effective approaches to differentiation in the SME, where the nature of ownership, the operating environment strategic orientation and e-commerce (O'Regan et al., 2006), all are impactful. Additionally, and in line with our findings, social and business networks also have been found as contributory factors (Presutti and Odorici, 2019). Other sources include attributes associated with innovation and organisational capability (Falahat et al., 2020). Our evidence suggests that the former is less important than the latter, with our respondents highlighting customer service as a key capability, where we argue that this is the basis of their competitive strategy. This is not suggesting innovation be disregarded, it is clearly important (Nicholas et al., 2011), but it is something not easily adopted and implemented, and one not always beneficial for every small firm (Rosenbusch et al., 2011). Equally, customer service is not a uniform category and we are not laying out prescriptive guidelines here. Excellent customer service is not by implication a one size fits all approach, as it will vary from firm to firm, dependent on circumstances and the nature of the customer relationships being developed. All organisations need to establish their own practices, in order to be successful and, by concentrating on and evolving the nature of the current relationship with customers, it is possible to argue that good reputations can be spread and new customers attracted.

This emphasis on service suggests that our firms are acting nimbly, responding to and anticipating, current customer needs. This strategic practice orienta- 
tion to service and relationships, is complemented by the approach to costs adopted. Our respondents make the point about the importance of keeping down the costs of goods supplied, in order to secure sales from appropriately priced products. It would be wrong to suggest then, that these firms are attempting to operate to a cost leadership strategy, as prices are part of a total value bundle customers receive. It is important to make sure that customers are highly satisfied with the bundle of value they receive as it will help to keep them coming back (Buttle and Maklan, 2019; Gummesson, 2017). This emphasis on relationship building in our research is also evident in the dealings with suppliers and others in networks. Concomitantly then, our research shows that additionally, there are also practices in place to build relationships with key alliance partners, in order to maximise value for the end receiver of products and services, an argument evidenced by the Anglo Australian School of relationship marketers (Christopher et al., 2013).

\section{Concluding Comments}

Initially, some thoughts on the papers' limitations. Firstly while the owner managers of the companies represented here have produced very useful sights into operations, our perspective on business practices may have been enhanced, if we have been able to observe actual events. This could have included for example, viewing particular customer service practices in action. Also, whilst most of our respondents here are from the UK, included in our sample, are firms from Singapore, and it would have been interesting to delve into the possible different types of practices that exist between firms in these countries. Here culture might be of importance as a factor. And, whilst we do have a relatively good cross-section of firms in our sample, they are mainly of the smaller SME variety, so it would be useful to consider how some of the larger types of SME deal with the issue of competitive strategy. Whether or not they place the same degree of emphasise on networks, for example, in obtaining results in the market place. It would also be useful for future research to think about competitive strategy more widely. This could examine the extent to which issues such as the nature of the changing global business environment, the firms strategic orientation be it short or long term and the question of e-commerce, all put pressure on the implementation of competitive strategy. These could all be examined from a practice perspective.

In a more general reflection here, with practice theory being based on the idea that in the continual flow of organisational life it is possible to identify blocks of activities, we have argued here that the model proposed in table one, is organised so as to illustrate SME practices as organised assemblages of actions that enable the companies involved to build a competitive strategy. Interestingly, the emphasis in our organisations appears not to be on future planned innovations, but more on the here and now of their service-based customer focused competitive strategy practices. Giving prominence to the here and now means also that 
strategy is emergent, yet dynamically and closely focused, where important practices are used to build a strong competitive position. Additional research using a wider range of research tools would perhaps be able to uncover these practices in more detail in possibly, a wider range of organisations.

Additionally, it is quite feasible that other studies will potentially uncover alternative types of practice and we hope the limited research here, will engender some further cross comparative work on competitive strategy and practice. Of course, practices are dynamic and may well change over time, being dependent on both structural changes and the actions of the individual. And of course, major events like global pandemics will influence the nature of practices as people change them in response to structural imperatives. In reflecting more deeply on business processes among the attractions of theories of practice is that they are neither totally individualistic nor totally holistic. In the latter case, people's actions are controlled by forces external to them. Equally, practice theory recognises that individuals cannot act in unfettered ways. Instead, practice theory presents a pluralistic and flexible picture of the composition of social life, one opposed to any type of grand theory of social action. We argue that practice theory can consequently, successfully accommodate the complexities, the differences and the exactitudes of the business world and in our case, the world of the small business has been opened up through the research carried out.

\section{Conflicts of Interest}

The authors declare no conflicts of interest regarding the publication of this paper.

\section{References}

Abadi, R. R., Nursyamsi, I., \& Syamsuddin, A. R. (2020). Effect of Customer Value and Experiential Marketing to Customer Loyalty with Customer Satisfaction as Intervening Variable (Case Study on Gojek Makassar Consumers). The Asian Journal of Technology Management, 13, 82-97. https://doi.org/10.12695/ajtm.2020.13.1.6

Altinay, L., Madanoglu, M., De Vita, G., Arasli, H., \& Ekinci, Y. (2016). The Interface between Organizational Learning Capability, Entrepreneurial Orientation, and SME Growth. Journal of Small Business Management, 54, 871-891. https://doi.org/10.1111/jsbm.12219

Ardley, B. C., \& Quinn, L. (2014). Practitioner Accounts and Knowledge Production: An Analysis of Three Marketing Discourses. Marketing Theory, 14, 97-118. https://doi.org/10.1177/1470593113512322

Arnett, D. B., \& Wittmann, C. M. (2014). Improving Marketing Success; the Role of Tacit Knowledge Exchange between Sales and Marketing, Journal of Business Research, 67, 324-331. https://doi.org/10.1016/j.jbusres.2013.01.018

Ashton, S. (2014). Researcher or Nurse? Difficulties of Undertaking Semi-Structured Interviews on Sensitive Topics. Nurse Researcher, 22, 27. https://doi.org/10.7748/nr.22.1.27.e1255

Audretsch, D. B., \& Vivarelli, M. (1996). Firm's Size and R\&D Spillovers: Evidence from Italy. Small Business Economics, 8, 249-258. https://doi.org/10.1007/BF00388651 
Ballantyne, D. (2004). Dialogue and Its Role in the Development of Relationship Specific Knowledge. Journal of Business and Industrial Marketing, 19, 114-123. https://doi.org/10.1108/08858620410523990

Bourdieu, P. (1984). Distinction: A Social Critique of the Judgement of Taste. London: Routledge.

Buhr, N. (2002). A Structuration View on the Initiation of Environmental Reports. Critical Perspectives on Accounting, 13, 17-38. https://doi.org/10.1016/S1045-2354(00)90441-6

Buttle, F., \& Maklan, S. (2019). Customer Relationship Management: Concepts and Technologies. London: Routledge. https://doi.org/10.4324/9781351016551

Cavusgil, S. T., Calantone, R. J., \& Zhao, Y. (2003). Tacit Knowledge Transfer and Firm Innovation Capability. Journal of Business \& Industrial Marketing, 18, 6-21. https://doi.org/10.1108/08858620310458615

Christopher, M., Payne, A., \& Ballantyne, D. (2013). Relationship Marketing. London: Taylor \& Francis. https://doi.org/10.4324/9780080516042

Deakins, D., \& Freel, M. (2012). Entrepreneurship and Small Firms (6th ed.). Berkshire: McGraw-Hill Higher Education.

Echeverri, P., \& Skålén, P. (2011). Co-Creation and Co-Destruction: A Practice-Theory Based Study of Interactive Value Formation. Marketing Theory, 11, 351-373. https://doi.org/10.1177/1470593111408181

European Commission (EC) (2015). User Guide to the New SME Definition. https://ec.europa.eu/regional_policy/sources/conferences/state-aid/sme/smedefinitiong uide_en.pdf

Falahat, M., Ramayah, T., Soto-Acosta, P., \& Lee, Y. Y. (2020). SMEs Internationalization: The Role of Product Innovation, Market Intelligence, Pricing and Marketing Communication Capabilities as Drivers of SMEs' International Performance. Technological Forecasting and Social Change, 152, Article ID: 119908. https://doi.org/10.1016/j.techfore.2020.119908

Giddens, A. (1984). The Constitution of Society, Outline of the Theory of Structuration. Cambridge: Polity Press.

Gummesson, E. (2017). From Relationship Marketing to Total Relationship Marketing and Beyond. Journal of Services Marketing, 31, 16-20.

https://doi.org/10.1108/JSM-11-2016-0398

Hackley, C. (2000). Silent Running: Tacit, Discursive and Psychological Aspects of Management in a Top UK Advertising Agency. British Journal of Management, 11, 239-254. https://doi.org/10.1111/1467-8551.00164

Hackley, C. (2019). Qualitative Research in Marketing and Management: Doing Interpretive Research Projects (2th ed.). Abingdon: Routledge. https://doi.org/10.4324/9780429446801

Hanna, V., \& Walsh, K. (2002). Small Firm Networks: A Successful Approach to Innovation? R\&D Management, 32, 201-207. https://doi.org/10.1111/1467-9310.00253

Hapsari, R., Clemes, M. D., \& Dean, D. (2017). The Impact of Service Quality, Customer Engagement and Selected Marketing Constructs on Airline Passenger Loyalty. International Journal of Quality and Service Sciences, 9, 21-41. https://doi.org/10.1108/IJQSS-07-2016-0048

Hargreaves, T. (2011). Practicing Behaviour Change: Applying Social Practice Theory to Pro-Environmental Behaviour Change. Journal of Consumer Culture, 11, 79-99. 
https://doi.org/10.1177/1469540510390500

Hooley, G. J., Piercy, N., Nicoulaud, B., \& Rudd, J. (2017). Marketing Strategy and Competitive Positioning. London: Pearson Education.

Hu, H. H., Kandampully, J., \& Juwaheer, T. D. (2009). Relationships and Impacts of Service Quality, Perceived Value, Customer Satisfaction, and Image: An Empirical Study. The Service Industries Journal, 29, 111-125. https://doi.org/10.1080/02642060802292932

Jones, R., \& Rowley, J. (2009). Presentation of a Generic “EMICO” Framework for Research Exploration of Entrepreneurial Marketing in SMEs. Journal of Research in Marketing and Entrepreneurship, 11, 5-21. https://doi.org/10.1108/14715200911014112

Jones, R., Suoranta, M., \& Rowley, J. (2013). Strategic Network Marketing in Technology SMEs. Journal of Marketing Management, 29, 671-697. https://doi.org/10.1080/0267257X.2013.797920

Kaptan, Y. (2013). “We Just Know!” Tacit Knowledge and Knowledge Production in the Turkish Advertising Industry. Journal of Consumer Culture, 13, 264-283. https://doi.org/10.1177/1469540513482601

Kvale, S. (1996). InterViews. London: Sage.

Love, J. H., \& Roper, S. (2015). SME Innovation, Exporting and Growth: A Review of Existing Evidence. International Small Business Journal, 33, 28-48. https://doi.org/10.1177/0266242614550190

Man, T. W., Lau, T., \& Chan, K. F. (2002). The Competitiveness of Small and Medium Enterprises: A Conceptualization with Focus on Entrepreneurial Competencies. Journal of Business Venturing, 17, 123-142. https://doi.org/10.1016/S0883-9026(00)00058-6

Marshall, C., \& Rossman, G. (2016). Designing Qualitative Research. London: Sage.

Menelec, V., \& Jones, B. (2015). Networks and Marketing in Small Professional Service Businesses. Journal of Research in Marketing and Entrepreneurship, 17, 193-211. https://doi.org/10.1108/JRME-03-2015-0023

Morris, M. H., Schindehutte, M., \& LaForge, R. W. (2002). Entrepreneurial Marketing: A Construct for Integrating Emerging Entrepreneurship and Marketing Perspectives. Journal of Marketing Theory and Practice, 10, 1-19. https://doi.org/10.1080/10696679.2002.11501922

Nicholas, J., Ledwith, A., \& Perks, H. (2011). New Product Development Best Practice in SME and Large Organisations: Theory vs Practice. European Journal of Innovation Management, 14, 227-252. https://doi.org/10.1108/14601061111124902

Nicolini, D. (2009). Articulating Practice through the Interview to the Double. Management Learning, 40, 195-212. https://doi.org/10.1177/1350507608101230

Nicolini, D. (2012). Practice Theory, Work, and Organisation: An Introduction. Oxford: Oxford University Press.

O'Donnell, A. (2011). Small Firm Marketing: Synthesising and Supporting Received Wisdom. Journal of Small Business and Enterprise Development, 18, 781-806. https://doi.org/10.1108/14626001111179802

O'Regan, N., Ghobadian, A., \& Gallear, D. (2006). In Search of the Drivers of High Growth in Manufacturing SMEs. Technovation, 26, 30-41. https://doi.org/10.1016/j.technovation.2005.05.004

Paltridge, B. (2006). Discourse Analysis. London: Continuum Books.

Presutti, M., \& Odorici, V. (2019). Linking Entrepreneurial and Market Orientation to the SME's Performance Growth: The Moderating Role of Entrepreneurial Experience and 
Networks. International Entrepreneurship and Management Journal, 15, 697-720. https://doi.org/10.1007/s11365-018-0533-4

Pullen, A., De Weerd-Nederhof, P., Groen, A., Song, M., \& Fisscher, O. (2009). Successful Patterns of Internal SME Characteristics Leading to High Overall Innovation Performance. Creativity and Innovation Management, 18, 209-223. https://doi.org/10.1111/j.1467-8691.2009.00530.x

Reckwitz, A. (2002). Toward a Theory of Social Practices: A Development in Culturalist Theorizing. European Journal of Social Theory, 5, 243-263. https://doi.org/10.1177/13684310222225432

Røpke, I. (2009). Theories of Practice-New Inspiration for Ecological Economic Studies on Consumption. Ecological Economics, 68, 2490-2497. https://doi.org/10.1016/j.ecolecon.2009.05.015

Rosenbusch, N., Brinckmann, J., \& Bausch, A. (2011). Is Innovation Always Beneficial? A Meta-Analysis of the Relationship between Innovation and Performance in SMEs. Journal of Business Venturing, 26, 441-457. https://doi.org/10.1016/j.jbusvent.2009.12.002

Sadiku-Dush, N., Dana, L. P., \& Ramadani, V. (2019). Entrepreneurial Marketing Dimensions and SMEs Performance. Journal of Business Research, 100, 86-99.

https://doi.org/10.1016/j.jbusres.2019.03.025

Schatzki, T. R. (1996). Social Practices: A Wittgensteinian Approach to Human Activity and the Social. Cambridge: Cambridge University Press. https://doi.org/10.1017/CBO9780511527470

Schau, H. J., Muñiz Jr., A. M., \& Arnould, E. J. (2009). How Brand Community Practices Create Value. Journal of Marketing, 73, 30-51. https://doi.org/10.1509/jmkg.73.5.30

Shove, E., \& Pantzar, M. (2005). Consumers, Producers and Practices: Understanding the Invention and Reinvention of Nordic Walking. Journal of Consumer Culture, 5, 43-64. https://doi.org/10.1177/1469540505049846

Tam, J. L. M. (2004). Customer Satisfaction, Service Quality and Perceived Value: An Integrative Model. Journal of Marketing Management, 20, 897-917. https://doi.org/10.1362/0267257041838719

Vaara, E., \& Whittington, R. (2012). Strategy-as-Practice: Taking Social Practices Seriously. Academy of Management Annals, 6, 285-336. https://doi.org/10.5465/19416520.2012.672039

Warde, A. (2005). Consumption and Theories of Practice. Journal of Consumer Culture, 5, 131-153. https://doi.org/10.1177/1469540505053090

Watson, T. J. (1995). Rhetoric, Discourse and Argument in Organizational Sense Making: A Reflexive Tale. Organization Studies, 16, 805-821. https://doi.org/10.1177/017084069501600503

Wei, K. K., \& Nair, M. (2006). The Effects of Customer Service Management on Business Performance in Malaysian Banking Industry: An Empirical Analysis. Asia Pacific Journal of Marketing and Logistics, 18, 111-129. https://doi.org/10.1108/13555850610658264

Wilson, R. M., \& Gilligan, C. (2012). Strategic Marketing Management. London: Routledge. https://doi.org/10.4324/9780080468570 